\title{
A modular system for trapping and mass-marking bumblebees: applications for studying food choice and foraging range ${ }^{1}$
}

\author{
Andrew P. MARTIN ${ }^{\mathrm{a} *}$, Norman L. CARRECK ${ }^{\mathrm{a}}$, Jennifer L. SwAIN ${ }^{\mathrm{a}}$, Dave GouLSON ${ }^{\mathrm{b}}$, \\ Mairi E. KNIGHT ${ }^{\mathrm{b}}$, Roddy J. HALE ${ }^{\mathrm{c}}$, Roy A. SANDERSON ${ }^{\mathrm{c}}$, Juliet L. OSBORNE ${ }^{\mathrm{a}}$ \\ a Plant and Invertebrate Ecology Division, Rothamsted Research, Harpenden, Hertfordshire, AL5 2JQ, UK \\ ${ }^{\mathrm{b}}$ Ecology and Evolution Group, University of Southampton, Bassett Crescent East, Southampton, SO16 7PX, UK \\ ${ }^{c}$ Institute for Research on Environment and Sustainability, Devonshire Building, University of Newcastle, \\ Newcastle-upon-Tyne, NE1 7RU, UK
}

Received 12 May 2005 - revised 10 August 2005 - accepted 22 August 2005

\begin{abstract}
Two new techniques for the study of bumblebee behavioural ecology are described. Interchangeable nest entrance modules allow (i) unimpeded bee traffic, (ii) trapping of incoming foragers for counting and removal of pollen loads; or (iii) colour marking of bees leaving the colony using dye powder. The forager traps captured all returning foragers while in place and 35\% of them were carrying pollen loads. During the four week experiment, the percentage of mixed pollen loads decreased and the proportion of pollen loads from mass-flowering resources increased. The dye dispensers automatically marked $86 \%$ of foragers as they left the colony (approximately 28 bees per hour), and $37 \%$ of returning bees were marked. Different colours were used for bees in each colony, which could then be observed in the field.
\end{abstract}

Bombus / pollen collection / mark-reobservation / foraging patterns / mass marking / experimental device

\section{INTRODUCTION}

Expanding interest in the value of bumblebees as crop pollinators (Griffiths and Robberts, 1996; Osborne and Williams, 1996) and concern about the decreasing range of several bumblebee species in the UK (Williams, 1982, 1996) have resulted in an increased number of research projects investigating bumblebee ecology and behaviour. There is consequently a need for specialised equipment in these studies. We have designed solutions to two specific problems in the field studies of bumblebees. First, a method for trapping bumblebee foragers as they return to the nest, and collecting their pollen loads; and second, a method for mass- marking bumblebee foragers for mark-reobservation studies over the landscape.

The use of pollen traps of various designs (Todd and Bishop, 1940; Synge, 1947; Smith, 1963; Stewart and Shimanuki, 1970) to collect pollen loads from honeybees as they return to their hive has provided data on foraging behaviour (Goodwin and Perry, 1992), competition between bee species (Kribbe, 1993; Fotler, 1995) and food preferences (Parent et al., 1990). To our knowledge, automated pollen capture from bumblebee colonies has not been reported. Past studies of pollen brought into bumblebee colonies have relied on observers sitting at the entrance to a colony, capturing bumblebees individually (Brian, 1952; Kearns

\footnotetext{
* Corresponding author: andrew.martin@bbsrc.ac.uk

${ }^{1}$ Manuscript editor: Jean-Noël Tasei
} 
and Inouye, 1993), or analysis of meconia from dissected colonies (Løken, 1961; EdwardsAnderka and Pengelly, 1970). A pollen trap of mesh design, as used on honeybee colonies (Farrer, 1934; Synge, 1947; Smith, 1963), is not effective for bumblebee colonies. This is because bumblebee workers are much more variable in size (Goulson et al., 2002) than honeybees, and also because apertures (or even spaces between rigid combs or fibre brushes) large enough to allow pollen-carrying foragers to pass fail to dislodge pollen loads, since bumble bees neatly tuck their legs in behind them when passing such obstructions (Carreck, unpublished data). Manual capture of foragers is time-consuming, and returning bees are often deterred from entering their nests by an experimenter waiting to ambush them. The new forager traps described in this paper facilitate their capture, and present the same design as the normal entrance to incoming bees, speeding up the data-gathering process with less disturbance to bumblebee behaviour.

Bumblebee mark-reobservation experiments have provided detailed information on spatial foraging patterns (Dramstad, 1996; Saville et al., 1997). They have relied on marking bees individually with paint or numbered discs. This is time-consuming and restricts the number of bees that can be considered in the study, typically, to a few hundred. To examine further the relationship between bumblebee nesting sites and forage use, a method for marking larger numbers of foragers is required; hence our design of a powder dye dispenser to mark bumblebees as they leave the colony without disturbing them. Powder dye dispensers have been used on honeybee colonies (Howpage et al., 1998) but to our knowledge, no design has been reported for use on bumblebee colonies.

We report on a modular system for modifying the entrance to bumblebee colonies (a) to capture incoming foragers without harm or disturbance from an experimenter, so that pollen loads can be removed and examined, to provide information on foraging patterns, analogous to that provided by a pollen trap on a honeybee hive, and (b) to automatically mass mark foragers as they leave, providing a tool for large scale mark-reobservation experiments. Catch rates of the traps, pollen loads from the captured foragers, final nest weights of the colonies, and dye-marking efficiency were recorded; providing data which were analysed to test the robustness and suitability of the modular system.

\section{MATERIALS AND METHODS}

\subsection{Colony accommodation and deployment}

Twenty eight Bombus terrestris audax colonies were reared by Koppert BV (Netherlands) from queens caught locally in Hertfordshire, UK in spring 2002. Four colonies were set out at each of seven sites along a $1500 \mathrm{~m}$ transect on Rothamsted Farm, Hertfordshire, during the summer of 2002. Each colony was delivered in a ventilated plastic box within a corrugated cardboard box, with syrup and pollen supplies for travelling. Each cardboard nestbox was weatherproofed by housing it in a wooden box comprising a brood chamber, floorboard and roof from a Modified British National honeybee hive (British Standards Institution, 1960). The hive entrance, normally a slot running the whole width of the hive, was reduced to a small aperture $(40 \times 10 \mathrm{~mm})$ by a wooden insert (Fig. 1a). A $40 \mathrm{~cm}$ piece of polypropylene rope ( $8 \mathrm{~mm}$ diameter) with heat-welded ends to prevent fraying was secured to the hive floor adjacent to the internal side of the entrance module (Fig. 1b). The other end was secured next to the entrance hole in the nest box. The rope therefore formed a bridge between the entrance to the nest box and the entrance of the hive.

The hive roofs, clad in sheet steel, became very hot in direct sunlight. Each hive was therefore fitted with a sunshade comprising a square sheet of oriented strand board (exterior grade chipboard) $(61 \times$ $61 \mathrm{~cm}$ ) painted white, with stepped wooden blocks on its lower surface, to maintain an air gap (25 mm) between shade and roof. The maximum temperature inside two adjacent hives sited away from shade, one fitted with a sunshade and the other not, was recorded over four days in June 2002.

A modular system of three interchangeable entrances was devised (Fig. 2), comprising (a) a standard straight-through entrance allowing bees to enter and leave freely, (b) a forager trap for capturing incoming foragers, and (c) a dye dispenser for massmarking foragers emerging from the hive. All three modules were made from plastic boxes $(75 \times 75 \times$ $75 \mathrm{~mm}$, Stewart plastics, UK) with removable lids. Experiments using these entrance modules (described below) were conducted over four weeks ending on 2nd August 2002. The colonies were then removed from the field and, after removing adult bees, the nests were weighed to provide an indicator of the maximum size the colonies attained during the 

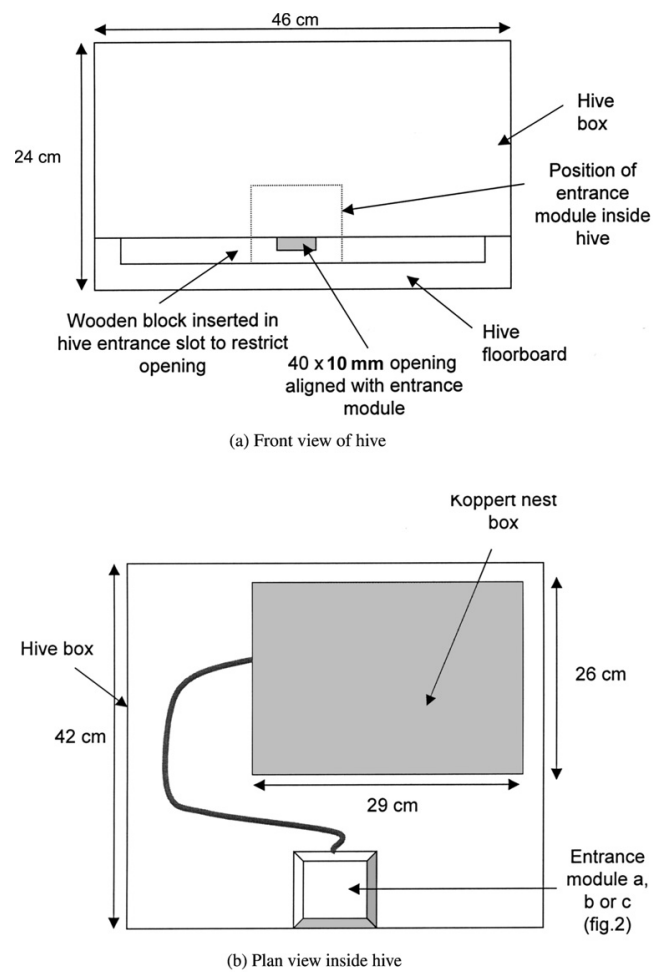

Figure 1. Experimental hive showing (a) front view showing hive entrance-reducing block, (b) arrangement of Koppert nest box, rope bridge and entrance module within hive.

experiments. During the experimental period, the most plentiful forage within $2 \mathrm{~km}$ of the colonies was a field of Borago officinalis (borage), three fields of spring sown Brassica napus (oilseed rape), wild Rubus fructicosus (bramble) in the hedgerows and unknown flowering plants in the floriferous gardens adjacent to Rothamsted farm (Osborne et al., unpublished data).

The standard entrances, dye dispensers and forager traps were labelled with colony number, and used colony-specifically. While dye dispensers or forager traps were in use, the standard entrances were stored inside the hive box in the front right corner, and immediately replaced when the dye-marking or forager trapping period had ended. This ensured that any colony-specific odour recognition cues were common to all three different entrances.

\subsection{Standard entrance}

The standard entrance was a plastic specimen tube $(30 \mathrm{~mL}$, Sterilin), with its threaded top and conical base removed, which was cemented across the box between holes ( $25 \mathrm{~mm}$ to match the tube's internal diameter) bored in the front and rear walls (Fig. 2a). Bees leaving or entering the hive therefore encountered the plastic box and the $25 \mathrm{~mm}$ hole in its front or rear wall, either from the end of the rope bridge when leaving, or from the opening in the entrance block when arriving. The forager trap and the dye dispenser presented similar entrance or exit architecture to the bees.

\subsection{Forager trap}

The forager trap module was identical to the standard entrance except that the Sterilin tube extended for only half of the box's depth, and terminated in a hole $(7 \mathrm{~mm})$, formed by cutting the tip from its tapered conical base (Fig. 2b). The aperture in the rear inside-facing wall of the box was covered by rigid plastic mesh ( $2 \mathrm{~mm}$ hole size $)$ cemented in position. This provided odour continuity from the nest to incoming bees outside at the entrance, while preventing bees inside the hive box from entering the trap and from leaving the hive while the trap was in place. Bees returning to the hive entered the trap as they would the standard entrance, and emerged into the plastic box via the hole at the tapered end of the tube. They could not then continue into the hive because of the mesh covering the hole in the rear wall, nor could they leave the way they entered because of the "lobster pot" design of the tapered entrance tube.

Forager traps were placed in the hives instead of the standard entrances for 15-30 min. They were then removed from the hive, the trap's entrance tube was blocked with a tissue paper plug, and $\mathrm{CO}_{2}$ was delivered to the bees via the mesh-covered hole in the back of the box, from a modified "Sodastream ${ }^{\circledR}$ ", carbonated drinks maker (Killick-Kendrick, 1993). A two second burst was sufficient to fill the trap box with a $\mathrm{CO}_{2}$ rich atmosphere, in which the bees were enclosed by placing the box mesh down. After $30 \mathrm{~s}$ all the bees had become motionless and they were recovered from the trap via its removable lid. Pollen loads were counted, their colours scored and a sample from each was removed for microscopic examination to identify the plant genera and species represented by each colour. The bees were returned to the trap as they began to recover from the anaesthetic. They were taken back to the natal colony and released inside the hive box. Bees from the 28 experimental colonies were trapped on return to their nests from foraging trips on seven occasions over a four week period during July, 2002. Average forager catch rate and pollen forager catch rate for each colony were calculated from all seven trapping occasions. To test whether catch rate was an indicator of colony success, the relationship between these catch rates and nest weight at the end of the experiment 


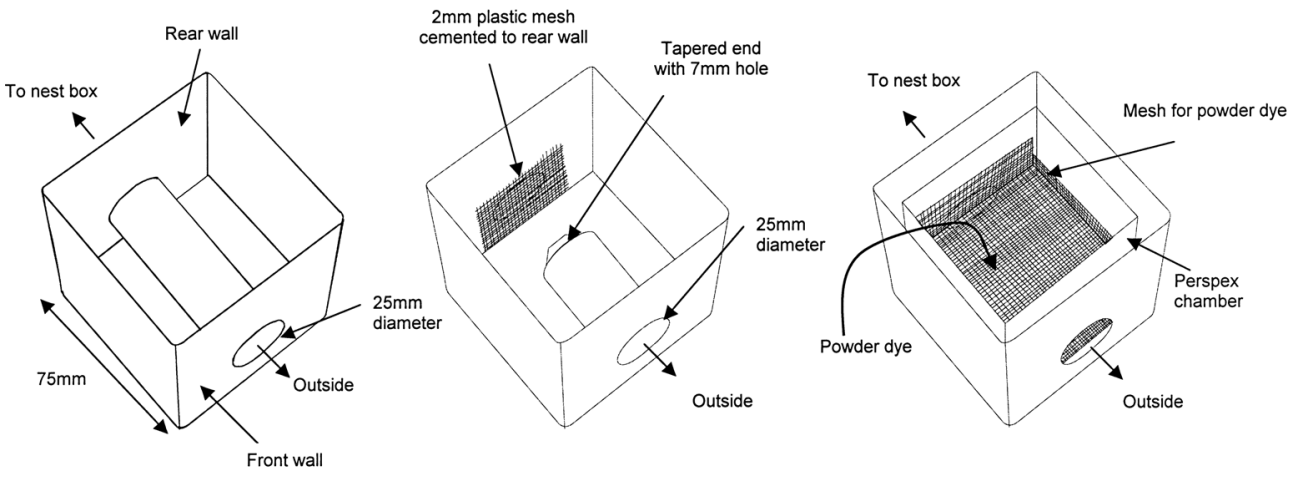

(a) Standard entrance

(b) Forager trap

(c) Dye dispenser

Figure 2. Modular entrance system with lids removed: (a) standard entrance, (b) forager trap (c) dye dispenser.

was tested using linear regression, after confirming that the data did not require transformation. The proportions of pollen loads of different colours collected on each occasion over the sampling period were summarised for all colonies.

\subsection{Dye dispenser}

\subsubsection{Description}

The dye dispenser module was housed in an identical drilled plastic box, and was adapted from designs used for marking honeybees with similar dye powder (Boylan-Pett et al., 1991; Howpage et al., 1998). An open-topped Perspex ${ }^{\circledR}$ chamber, with muslin stretched across its base, was placed in the plastic box and supported so that there was a $6 \mathrm{~mm}$ gap beneath it, allowing just enough space for bees to crawl underneath. The muslin-floored chamber formed a reservoir for non-toxic particulate fluorescent plastic powder dye (Stirling Industrial Colours Ltd., Ciba Specialty Chemicals Ltd), and bees walking beneath the muslin (with which they were in contact because of its proximity to the floor) received a coating of the dye powder on the dorsal surface of the thorax and abdomen (Fig. 2c). Dye dispensers were positioned in place of the standard entrances at the end of the day before marked bee observations were due to begin, and about $30 \mathrm{~mL}$ of powdered dye was added to each so that all foragers from the colony had a high probability of being marked. A different colour dye was used for the seven sites (at each of which four colonies were placed) along the $1500 \mathrm{~m}$ transect.

\subsubsection{Effectiveness of marking}

To assess the effectiveness of the dye dispensers, the numbers of marked and unmarked bees leaving a colony over $10 \mathrm{~min}$ periods were counted, at each of the colonies fitted with a dye dispenser. This was repeated on three days during the four week experiment (17 July, 25 July, 2 August 2002). Observers were stationed $1.5 \mathrm{~m}$ from the colony entrances. Bees whose dye marking was visible to the naked eye at that distance were counted as marked, the rest were counted as unmarked. To examine whether or not the effectiveness of the dye dispensers was related to colony position and whether the same relationship held for the different sampling occasions, a logistic regression model (Generalized Linear Model (GLM) with binomial errors and logit link) was fitted to the numbers of leaving bees that were dye-marked out of the total observed at each colony on each occasion. Colony position was defined as distance from one end of the $1500 \mathrm{~m}$ transect, and the colonies at this end were close to a borage field.

\subsubsection{Persistence of dye on marked bees}

During the 10 min periods when outgoing bees were observed, the numbers of marked and unmarked bees returning to the colonies were also counted, to gain a measure of the persistence of dye powder on foraging bees. To examine whether dye persistence on the bees after foraging varied between colony site and sampling occasion, a similar GLM (i.e. with binomial errors and logit link) to that described above was performed on the proportion of bees returning to a colony that were dye-marked. However, in this analysis the percentage of marked 
bees leaving the colony (after transformation to logits $(\mathrm{p}=\ln (\mathrm{p} /(1-\mathrm{p}))$ with an adjustment to allow for 0 and $100 \%$ values) was used as a covariate. Also, quadratic terms were included for both the covariate and colony position to allow for any curvature in the relationships. Covariate terms were fitted first to confirm whether any of the percentage returning with dye could be explained by relationships with marking effectiveness of the dye dispenser. In both GLMs the presence of over-dispersion as indicated by a large residual mean deviance $(>>1)$ was allowed for by testing the ratios of the mean deviances for each model term to the residual mean deviance against the F-distribution.

\section{RESULTS}

\subsection{Accommodation}

The sunshades significantly reduced the temperature inside the hives, whether the day was sunny or overcast, by between 8 and $12{ }^{\circ} \mathrm{C}$ (Mann-Whitney U test, df $=3, P=0.02$ ). The mean $\mathrm{T}_{\max }$ inside the hive with a shade was $23.5^{\circ} \mathrm{C}( \pm 1.71)$, and inside the hive without a shade was $34.0^{\circ} \mathrm{C}( \pm 2.16)$, whilst mean ambient $\mathrm{T}_{\max }$ was $21.3^{\circ} \mathrm{C}( \pm 0.75)$.

\subsection{Forager traps}

The traps proved effective at collecting returning foragers. Of a total of 2799 bees caught on seven occasions during a four week period in July 2002, 978 were carrying pollen loads and 1821 were not. The mean forager catch rate per colony varied between 0.36 and 1.24 bees per min. There was a significant positive linear relationship between forager catch rate and nest weight at the end of the experiment $(P<0.001$, Fig. 3a, $)$, accounting for $37.3 \%$ of the variance. Average catch rate of pollen foragers per colony varied between 0.06 and 0.48 bees per min, and the relationship between pollen forager catch rate and nest weight was also highly significant $(P<0.001$, Fig. $3 b$ ), accounting for $43.4 \%$ of the variance. The proportion of bees caught in the traps that were carrying pollen was lowest $(0.27 \pm 0.044)$ on the last sampling occasion, highest $(0.52 \pm$ 0.043 ) on the second, and on the other five occasions it was between 0.3 and 0.4 .

The proportions of pollen of different colours collected by foragers varied over time on

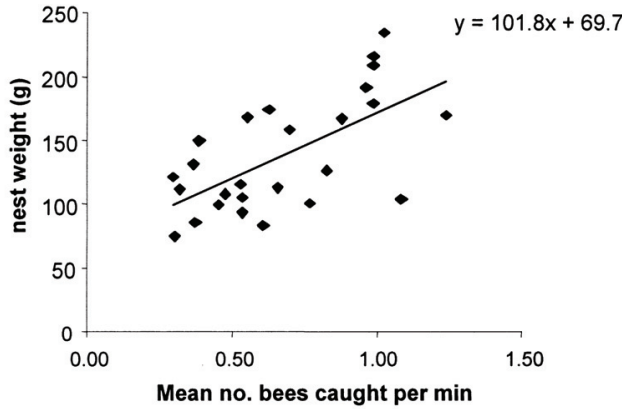

(a)

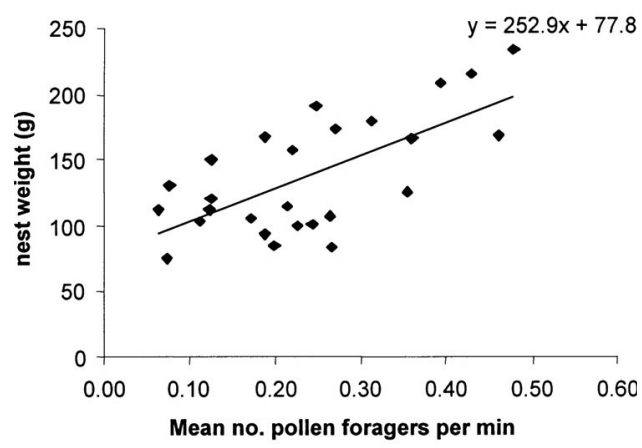

(b)

Figure 3. Relationship between final nest weight (bees removed) and (a) average number of foragers caught per min and (b) average number of pollen foragers caught per min.

the seven sampling occasions during the four week experiment (Fig. 4). Combining all occasions, $37 \%$ of all pollen loads sampled were cream coloured (microscopic examination showed this was $99 \%$ borage); $26 \%$ were yellow (mostly oilseed rape, with some hogweed, Heracleum sphondylium); $15 \%$ were grey (primarily bramble with some thistle, Cirsium spp.); 7\% were black (primarily common poppy, Papaver rhoeas) and $9 \%$ of loads were other single colours (e.g. brown, pale orange, green, not identified). The proportion of pollen loads from the mass flowering resources (borage, oilseed rape and bramble combined) increased from a total of about $50 \%$ at the beginning of the experiment, to over $89 \%$ by the fourth sampling occasion onwards (Fig. 4). Six percent of pollen loads $(n=56)$ contained at least two different pollen colours in discrete layers rather than as a single homogenous mixture. 
Pollen load colour by occasion

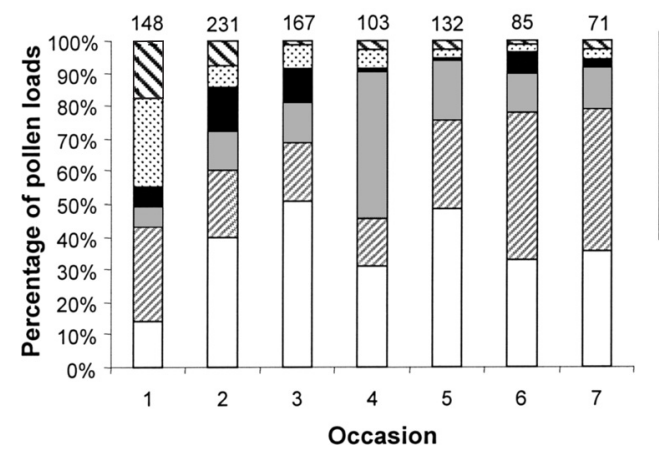

This suggests that the bees visited one plant species followed by another during a single trip, rather than visiting several plant species in mixed order. The proportion of these mixed loads decreased from $18 \%$ on the first sampling occasion to $3 \%$ or less on the third and subsequent sampling occasions (Fig. 4).

\subsection{Dye dispensers}

$30 \mathrm{~mL}$ of dye powder was sufficient to mark bees for three days, whilst the dispensers were in place. By watching each colony entrance for 10 min on each of three occasions, a total of 771 bee movements were recorded during 13.3 observer hours.

Of the 392 recorded departures on the 74 colony sampling occasions on which bees were observed leaving, 338 bees $(86.2 \pm 2.9 \%)$ were dye marked. Thus, on average, $4.6( \pm 0.4)$ marked bees left each colony over each $10 \mathrm{~min}$ period. On 56 of the 74 ten min observations, all of the bees leaving their colony were marked. There was no overall relationship between dye dispenser effectiveness and colony site position (test for overall slope: $\mathrm{F}_{1,68}=$ $1.19, P=0.279$ ), no differences amongst occasions (test for differences in intercept: $\mathrm{F}_{2,68}=$ $1.20, P=0.306$ ), and no interaction (test for differences in slopes: $\left.\mathrm{F}_{2,68}=2.15, P=0.124\right)$.

Of the 379 arrivals at the colonies, 141 $(37.2 \pm 3.7 \%)$ were marked, the remainder showing no dye discernable to the naked eye as they entered the nests. All of the bees returning were marked in only 9 out of 77 ten min observations where bees entered the colony. A full regression model was fitted to the 72 colony
$\Delta$ Mixed loads

ФOther single colours

-Black (mainly poppy)

$\square$ Grey (mainly bramble)

๑Yellow (mainly

oilseed rape)

$\square$ Cream (mainly borage)
Figure 4. Proportion of pollen loads sampled from forager traps of different colours, on separate occasions. Numbers above columns indicate number of loads sampled. Mixed = those loads with at least 2 different colours present in layers.

sampling occasions (when both departures and arrivals were recorded) including linear and quadratic explanatory terms, further terms to allow for differences between occasions and all interactions. This indicated that there were no significant differences between sampling occasions and no interaction terms were significant $(P>0.05)$. Therefore, a simpler model was fitted which contained only three terms: linear and squared terms in the covariate (proportion of marked bees leaving colony) and a linear term for colony position, with no interactions. A significant amount of the variation in the proportion of bees returning to the colony with dye was explained by the proportion of bees leaving the colony with dye (covariate linear term: $\mathrm{F}_{1,68}=14.11, P<0.001 ;$ quadratic term: $\mathrm{F}_{1,68}=$ $5.63, P=0.020)$, but there was also a significant relationship with colony site over and above that explained by the covariate terms $\left(\mathrm{F}_{1,68}=\right.$ 19.87, $P<0.001)$.

\section{DISCUSSION}

The forager trap and dye dispenser, together with appropriate colony accommodation, proved to be effective and robust techniques for monitoring large scale bumblebee foraging behaviour patterns.

\subsection{Colony accommodation}

Nest odour alone is probably not a reliable way for returning bees to find the nest entrance inside the dark hive, since the nest box is ventilated. In preliminary experiments, some bees 
were unable to find the inner nest box entrance, and started building cells on its roof. A rope bridge, connecting the hive entrance with the nest entrance, was therefore provided. There was then no secondary cell building outside the nest indicating that the bees could more easily find the nest entrance in darkness within the hive.

Most wild bumblebee colonies are in nests which are either underground or, if on the surface, shaded (Kells and Goulson, 2003). The location of experimental colonies is usually predetermined by considerations other than the microclimate of the site, so provision of shade from the full sun was needed without limiting access to the entrance modules inside the hives. The chosen design of a lightweight secondary roof fulfilled this requirement. The hives heated up on hazy as well as sunny days, but the sunshades reduced the solar heating considerably.

\subsection{Forager traps}

Compared to the dedicated pollen trap as fitted to honeybee colonies the forager traps had the disadvantage of requiring the experimenter to manually remove pollen loads from foragers. However, while the traps were fitted, all the pollen coming into the colony was sampled. Honeybee pollen traps only sample a proportion of the pollen loads brought to the hive; for example the design used by Goodwin and Perry (1992) had an efficiency of about $17 \%$. Apart from the collection of data on pollen being collected by the colony, the traps also caught nectar foragers and proved useful in monitoring overall colony foraging activity, which was highly significantly correlated with final nest weight. Forager catch rates could therefore be used as an approximate indicator of how much a colony is likely to grow, rather than simply recording a final (or maximum) weight, a measurement which can be compromised if colonies are attacked by wax moth or predators before an experiment is complete.

The length of time that the traps were in place was adjusted between 15 and $30 \mathrm{~min}$, depending on the activity of the colony, to produce a catch of around 20 foragers. Although the traps can accommodate many more bees than this, the subsequent processing (counting and removal of pollen loads for microscopic analysis) of more than 20 bees was difficult to complete before they recovered from the anaesthetic, unless they were narcotised by $\mathrm{CO}_{2}$ exposure for longer than 30 seconds. Exposure for less time immobilised the foragers for only a few seconds, so half a minute's exposure to $\mathrm{CO}_{2}$ was felt to give the best compromise between minimising its possible harmful effects and enabling reasonable numbers of bees per trap to be processed. Chilling the bees took far longer (10-20 min), and they recovered in only a few seconds in the summer ambient temperatures. Anaesthesia can affect bees' behaviour, for example B. terrestris workers were found to evict larvae following $\mathrm{CO}_{2}$ narcotisation (Pomeroy and Plowright, 1979). In honeybees, $\mathrm{CO}_{2}$ exposure of 30 seconds or more has been found to reduce pollen gathering (Ebadi et al., 1980). We did not compare the behaviour of previously narcotised bumblebee foragers with untreated ones, but the proportion of foragers bringing in pollen loads was no lower at the end of the trapping period than at the beginning. How often the same individuals were likely to be caught and exposed to $\mathrm{CO}_{2}$ depends on their longevity, estimates of which vary widely in the literature (Rodd et al., 1980; Morse, 1986) and the frequency with which they return to the nest.

Using the forager traps to accumulate incoming foragers, and then processing them trap by trap has the disadvantage of requiring $\mathrm{CO}_{2}$ anaesthesia, whereas other methods do not. For example, Kearns and Inouye (1993) describe a device inserted between a nest box and an entrance tunnel which allows corbicular loads to be removed from single bees quickly and without narcotisation. However, this method requires an experimenter to wait by the colony continuously and capture the bees one by one. In our experiments, two operators (one placing and removing traps and transporting them to and from the other, who narcotised the bees and removed and recorded pollen loads) could process on average 350 bees from 28 colonies at seven sites in half a day. If the colony sites were much more than $250 \mathrm{~m}$ apart, it would probably be quicker to process the bees at the sites rather than transport them to a central point; but in either case the forager traps allow many more bees to be caught and processed than would be possible by intercepting them individually at each colony. 
Further study is required to investigate the possible harmful side effects of $\mathrm{CO}_{2}$ anaesthesia and of possibly capturing the same bees repeatedly when using the forager traps. Further experiments using the traps could also test alternative hypotheses explaining the decline in the number and proportion of mixed pollen loads over the course of this experiment, which could either reflect changes in the mix of available forage as the experiment proceeded; or indicate odour-based information transfer from experienced to naive foragers so that those starting to forage later were more likely to seek out forage corresponding to the dominant odours coming into the nest.

\subsection{Dye dispensers}

This method for mass-marking bees enables far more bees to be marked than in previous experiments; potentially thousands of workers, and is analogous to the powder dye techniques described for honeybees by Dhaliwal and Sharma (1973) and Howpage et al. (1998). However, it is limited to a colony- or day-specific colour and it is inappropriate for experiments where individual bees need to be identified, for example using paint marks or coloured/numbered plastic tags (e.g. Kwak, 1987; Osborne et al., 1999). Marking of individual foragers could be facilitated by using the traps described here to select only bees which are actively foraging, from particular colonies of interest, and thus causing less disturbance to the colony than removing bees directly from the nest.

Bees leaving the colony via the dye dispensers were almost all effectively marked (overall $86 \%$, median per colony $100 \%$ ). Variation in the proportion marked was not significantly affected by bee traffic at the colony site or sampling occasion, suggesting that effectiveness of these dye dispensers was consistent and robust, and this enables comparisons to be made between observations of marked bees from different colonies placed in the field.

However, most of the bees returning to the colonies $(63 \%)$ were not visibly marked. The dye powder was therefore being lost during foraging trips. This could be during grooming, when the bee moves pollen (and dye particles) from its hairy coat either to discard it, or to pack it into the corbiculae. The dye could also be dis- lodged during flower handling, or during flight; when the bees' bodies are vibrating at wingbeat frequency as well as being subjected to a considerable airflow at an airspeed of about $7 \mathrm{~m} \mathrm{~s}^{-1}$ (Riley et al., 1999). The implication for counts of marked bees on forage plants in the field is that the method will underestimate numbers of foragers from the colony in question, since only a proportion of them (somewhere between $37 \%$ and $86 \%$ ) will still be visibly marked when seen (although dye particles may be visible under a microscope or UV lamp). In this experiment, the colonies with the lowest proportion of marked bees returning were furthest from the mass-flowering borage field. It is possible that some of the bees from these colonies were flying further to feed than those in colonies close to the borage field, and losing more dye during the longer commuting flight. Data derived from observations of marked bees on forage should therefore be weighted by factors derived from initial observations at the colony entrance (such as those described here) to assess the proportion of marked bees leaving and returning to each colony. The first studies on the spatial distribution of bumblebee foragers (Hale et al., Osborne et al., unpublished data) using the dye dispensers will be reported elsewhere.

This modular entrance system provides two different but complementary ways to examine and contrast forager patterns over landscape scale distances. The dye dispenser enables us to focus on the outgoing trip made by foragers to their food sources and to monitor their spatial distribution, whilst the forager trap allows us to examine the return trip and the variety and quantity of pollen returned to the colony.

\section{ACKNOWLEDGEMENTS}

We thank Ashley Tuck, Megumi Morigami and Debbie Winton for help with fieldwork, Dr. Adriaan van Doorn of Koppert BV for helpful discussions and advice, Linda Castle for drawings and Suzanne Clarke for statistical advice. This work was funded by the Biotechnology and Biological Sciences Research Council grants D16963, D16964 and D16965.

Résumé - Un système modulaire pour capturer et marquer les bourdons (Bombus spp.) : application à l'étude du choix de nourriture et du rayon de butinage. Nous décrivons deux nouvelles techniques qui facilitent l'étude du comportement de 
butinage des bourdons et de leur répartition spatiale sur le terrain (Fig. 1). Des modules interchangeables à l'entrée du nid permettent (i) aux bourdons d'entrer et de sortir du nid sans entraves (Fig. 2a), (ii) de piéger les butineuses qui rentrent pour les compter, les marquer individuellement et retirer leur charges de pollen (Fig. 2b) ou (iii) de marquer en masse les bourdons qui quittent la colonie à l'aide d'une poudre colorante. Nous avons réalisé des essais sur le terrain sur 28 colonies de Bombus terrestris afin de tester la robustesse et l'efficacité de ces dispositifs. Les tests sur les pièges à butineuses ont montré que toutes les butineuses rentrant à la ruche étaient capturées par les pièges lorsqu'ils restaient en place 20 à $30 \mathrm{~min}$. Les butineuses rentraient à la colonie au rythme de 0,36 à 1,24 abeille par min et $35 \%$ d'entre elles portaient des charges de pollen. La relation entre le taux de capture et le poids du nid à la fin de l'expérience était significative (Fig. 3). L'analyse pollinique a montré que, passée la première semaine après leur installation sur le terrain et ce durant quatre semaines, les colonies ramassaient moins de charges de pollen mixtes et une plus grande proportion de pollen à partir des ressources qui fleurissaient en masse (Fig. 4).

Les distributeurs de colorant pour le marquage en masse fournissent un moyen efficace pour marquer automatiquement la majorité des butineuses qui quittent le nid (86\% au total, médiane par colonie $100 \%$ ). La variation dans la proportion de bourdons marqués n'était pas significativement influencée par le trafic des bourdons, ni par la localisation de la colonie, ni par le moment de l'échantillonnage. Ceci suggère que les distributeurs de colorant fonctionnent de façon régulière et sont robustes. Cela permet de faire des comparaisons entre les observations des bourdons marqués issus de diverses colonies présentes sur le terrain. Pourtant seuls $37 \%$ des bourdons qui rentraient avaient des marques bien discernables et cette proportion était significativement influencée par la proportion de bourdons marqués au départ de la colonie. Les comportements de vol, de toilettage ou de butinage ont donc fait que le colorant a été perdu au cours des voyages. Il est donc nécessaire d'effectuer un calibrage préliminaire de l'efficacité des distributeurs avant de les utiliser sur le terrain. Des poudres de diverses couleurs peuvent être utilisées pour identifier la colonie d'où provient un bourdon vu sur le terrain.

Ce système d'entrée modulaire fournit deux moyens différents mais complémentaires pour étudier les caractéristiques et les contrastes du butinage à l'échelle du paysage. Le distributeur de colorant permet de se concentrer sur le voyage aller fait par les butineuses du nid vers la source de nourriture, alors que le piège à butineuses permet d'examiner le voyage de retour, la variété et la quantité de pollen rapporté à la colonie.

Bombus / récolte de pollen / comportement de butinage / marquage en masse / dispositif expérimental
Zusammenfassung - Ein modulares System zum Fangen und massenhaften Markieren von Hummeln: Anwendungen zur Untersuchung von Futterwahl und Grösse des Sammelgebiets. Wir beschreiben zwei neue Verfahren zur Erleichterung der Untersuchung des Sammelverhaltens von Hummeln und ihrer Verteilung im Freiland. Austauschbare Module am Nesteingang (Abb. 1) erlauben (i) die ungehinderte Bewegung der Hummeln aus dem und in das Nest (Abb. 2a); (ii) das Fangen zurückkehrender Sammlerinnen um sie zu zählen, Individuen zu markieren oder den Pollen abzusammeln (Abb. 2b); oder (iii) massenhafte Markierung von das Nest verlassenden Hummeln mit Farbpulver (Abb. 2c). Die Robustheit und Effektivität der Vorrichtungen wurde an 28 Bombus terrestris Völkern untersucht. Tests der Fallen zeigten, dass über einen Zeitraum von 20 bis 30 Minuten, in denen Fallen am Ausgang angebracht waren, sämtliche in das Nest zurückkehrenden Sammlerinnen von den Fallen gefangen worden waren. Die Sammlerinnen kehrten mit einer Rate von 0,36-1,24 Hummeln pro Minute zurück, $35 \%$ der Hummeln trugen Pollenladungen. Es bestand ein signifikanter Zusammenhang zwischen der Fangrate der Sammlerinnen und dem Gewicht des Nestes am Ende des Experiments (Abb. 3). Pollenanalysen zeigten, dass die Völker nach der ersten Woche nach ihrer Aufstellung über 4 Wochen weniger gemischte Pollenladungen und einen höheren Anteil von Pollen von Massenblütenangeboten sammelten (Abb. 4).

Die Farbverteiler zur massenhaften Markierung stellen eine effektive Möglichkeit zur automatischen Markierung fast der gesamten das Nest verlassenden Arbeiterinnen dar. Von den das Nest über den Farbverteiler verlassenden Hummeln waren fast alle farbmarkiert (insgesamt $86 \%$, Median über die Völker $100 \%$ ). Die Proportion der markierten Tiere wurde weder von dem Hummelverkehr, dem Aufstellungsort des Nestes oder dem Zeitpunkt der Probennahme signifikant beeinflusst. Dies legt nahe, dass die Effektivität der Farbverteiler robust und einheitlich war. Dies ermöglicht den Vergleich der Beobachtungen von markierten Tieren aus verschiedenen im Freiland aufgestellten Völkern. Allerdings hatten nur $37 \%$ der zurückkehrenden Hummeln sichtbar unterscheidbare Markierungen. Dieser Anteil hing signifikant von dem Anteil der beim Verlassen des Nestes markierten Tiere ab sowie vom Aufstellungsort des Nestes. Das Farbpulver ging daher während des Sammelns verloren, entweder durch das Fliegen, oder durch das Putzoder Sammelverhalten. Es ist deshalb notwendig, vor dem Einsatz der Farbverteiler in einem Freilandversuch deren Effektivität zu kalibrieren. Durch den Einsatz verschiedener Farben ist es möglich zu bestimmen, aus welchem Nest jede der im Freiland gesichteten Hummeln stammte.

Dieses modulare System stellt zwei verschiedene, sich aber ergänzende Wege zur Verfügung, um die Sammelmuster über skalierte Landschaftsentfernungen zu untersuchen und zu kontrastieren. Die 
Farbverteiler ermöglichen den Blick auf die auswärts gerichteten Flüge vom Nest an den Sammelort, die Sammlerinnenfallen dagegen den auf die Heimkehrflüge und die Vielfalt und Menge des dem Volk zugeführten Pollens.

\section{Bombus / Pollensammeln / Markieren und Wiederbeobachten / Sammelmuster}

\section{REFERENCES}

Boylan-Pett W.L., Hoopingarner R.A., Ramsdell D.C. (1991) A self-marking system to determine foraging populations of honey bees Apis mellifera L., Bee Sci. 1, 199-202.

Brian A.D. (1952) Division of labour and foraging in Bombus agrorum Fabricius., J. Anim. Ecol. 21, 223-240.

British Standards Institution (1960) Beehives, frames and wax foundation, British Standard BS 1300, 28 pp.

Dhaliwal H.S., Sharma P.L. (1973) Mass marking honeybees for behaviour studies, Indian $\mathrm{J}$. Entomol. 34, 85-86.

Dramstad W.E. (1996) Do bumblebees (Hymenoptera: Apidae) really forage close to their nests? J. Insect Behav. 9, 163-182.

Ebadi R., Gary N.E., Lorenzen K. (1980) Effects of Carbon Dioxide and Low Temperature Narcosis on Honey Bees Apis mellifera, Environ. Entomol. 9, 144-147.

Edwards-Anderka C.J., Pengelly D.H. (1970) Pollen analysis in the ecology of bees of the genus Bombus Latr. (Hymenoptera: Apidae) in southern Ontario, Proc. Entomol. Soc. Ont. 100, 170-176.

Farrer C.L. (1934) Bees must have pollen, Glean. Bee Cult. 62, 276-278.

Fotler G. (1995) Palynological studies of the specific competition between Apis mellifera and solitary Apoidea, Apidologie 26, 343-344.

Goodwin R.M., Perry J.H. (1992) Use of Pollen Traps to Investigate the Foraging Behavior of HoneyBee Colonies in Kiwifruit Orchards, N. Z. J. Crop Hortic. Sci. 20, 23-26.

Goulson D., Peat J., Stout J.C., Tucker J., Darvill B., Derwent L.C., Hughes W.O.H. (2002) Can alloethism in workers of the bumblebee, Bombus terrestris, be explained in terms of foraging efficiency? Anim. Behav. 64, 123-130.

Griffiths D., Robberts E. (1996) Bumble bees as pollinators of glasshouse crops, in: Matheson A. (Ed.), Bumble bees for pleasure and profit, International Bee Research Organisation, Cardiff, pp. 33-39.

Howpage D., Spooner-Hart R.N., Sheehy J. (1998) A successful method of mass marking honey bees, Apis mellifera, at the hive entrance for field experiments, J. Apic. Res. 37, 91-97.

Kearns C.A., Inouye D.W. (1993) Techniques for Pollination Biologists, University Press of Colorado, Niwot, Colorado, pp. 291-292.
Kells A.R., Goulson D. (2003) Preferred nesting sites of bumblebee queens (Hymenoptera: Apidae) in agroecosystems in the UK, Biol. Conserv. 109, $165-174$.

Killick-Kendrick R. (1993) "Sodastream" $\mathrm{CO}_{2}$ dispenser for killing insects, Antenna 17, 115.

Kribbe W. (1993) Bee versus bee? Dtsch. Bienen-J. 1, 366-368.

Kwak M.M. (1987) Marking a Bumble Bee without Anesthesia, Bee World 68, 180-181.

Løken A. (1961) Observations on Norwegian bumble bee nests (Hymenoptera, Apidae, Bombus), Nor. Entomol. Tidsskr. 11, 255-268.

Morse D.H. (1986) Predatory risk to insects foraging on flowers, Oikos 46.

Osborne J.L., Clark S.J., Morris R.J., Williams I.H., Riley J.R., Smith A.D., Reynolds D.R., Edwards A.S. (1999) A landscape-scale study of bumble bee foraging range and constancy, using harmonic radar, J. Appl. Ecol. 36, 519-533.

Osborne J.L., Williams I.H. (1996) Bumble bees as pollinators of crops and wild flowers, in: Matheson A. (Ed.), Bumble bees for pleasure and profit, International Bee Research Organisation, Cardiff, pp. 24-32.

Parent J., Feller-Demalsy M.J., Richard P.J.H. (1990) Pollen and nectar sources near Rimouski, Quebec, Canada, Apidologie 21, 431-445.

Pomeroy N., Plowright R.C. (1979) Larval ejection following $\mathrm{CO}_{2}$ narcosis of bumble bees, J. Kans. Entomol. Soc. 52, 215-217.

Riley J.R., Reynolds D.R., Smith A.D., Edwards A.S., Osborne J.L., Williams I.H., McCartney H.A. (1999) Compensation for wind drift by bumble bees, Nature 400, 126.

Rodd F.H., Plowright R.C., Owen, R.E. (1980) Mortality-Rates of Adult Bumble Bee Workers (Hymenoptera, Apidae), Can. J. Zool.-Rev. Can. Zool. 58, 1718-1721.

Saville N.M., Dramstad W.E., Fry G.L.A., Corbet, S.A. (1997) Bumblebee movement in a fragmented agricultural landscape, Agric. Ecosyst. Environ. 61, 145-154.

Smith M.V. (1963) The O A C Pollen Trap, Can. Bee J. 74, 4-5.

Stewart J.D., Shimanuki H. (1970) Rapid-Sample Pollen Trap for Honey Bees, J. Econ. Entomol. 63,1350

Synge A.D. (1947) Pollen collection by honeybees (Apis mellifera), J. Anim. Ecol. 16, 122-138.

Todd F.E., Bishop R.K. (1940) Trapping honeybeegathered pollen and factors affecting yields, J. Econ. Entomol. 33, 866-870.

Williams P.H. (1982) The Distribution and Decline of British Bumble Bees (Bombus Latr), J. Apic. Res. 21, 236-245.

Williams P.H. (1986) Environmental Change and the Distributions of British Bumble Bees (Bombus Latr), Bee World 67, 50-61. 